\title{
PENANAMAN NILAI-NILAI KARAKTER ANAK USIA DINI MELALUI PERMAINAN TRADISIONAL “GEMPURAN"
}

\author{
Wahyu Wulandari ${ }^{1}$, Oktavia Indah Permata Sary ${ }^{1}$, Rizka Prihatiningsih ${ }^{1}$ \\ Pascasarjana Pendidikan Anak Usia Dini, Universitas Negeri Semarang \\ Jl. Kelud Utara III No. 15, Semarang, Jawa Tengah \\ Penulis untuk korespondensi/ E-mail: wulansamboro@students.unnes.ac.id
}

\begin{abstract}
Abstrak - Penelitian ini bertujuan untuk mendeskripsikan nilai-nilai karakter yang terkandung dalam permainan tradisional Gempuran yang dilakukan oleh anak usia dini serta mengetahui dampak positif dan negatif dalam permainan tradisional Gempuran. Metode yang digunakan adalah kualitatif deskriptif. Pengumpulan data menggunakan teknik wawancara, observasi, dan dokumen. Dokumen yang dikumpulkan berfungsi sebagai data pendukung. Keabsahan data dilihat pada saat melakukan kegiatan permainan tradisonal Gempuran yaitu dengan mengecek dan mengobservasi segala aktivitas yang dilakukan oleh pendidik dan peserta didik dalam kegiatan pembentukan karakter melalui permainan Gempuran serta melakukan wawancara dengan pendidik. Hasil penelitian menunjukkan bahwa terdapat nilai-nilai karakter di dalam permainan tradisional Gempuran, yaitu rasa gotong royong, demokrasi, persatuan, dan kepatuhan. Nilai-nilai tersebut menjadi dasar bagi anak usia dini untuk menjalankan aktivitas pada tahap usia berikutnya. Secara garis besar ada dampak positif yang dapat berpengaruh besar terhadap pertumbuhan dan perkembangan anak seperti dapat bersosialisasi, anak merasa senang, anak dapat bersikap sportif, serta menjadikan anak kreatif. Adapun dampak negatifnya yaitu dalam hal waktu bermain, yang dapat diatasi dengan adanya pembatasan waktu dalam bermain. Dari dampak negatif yang diperoleh maka terdapat temuan baru yang didapatkan, yaitu bagaimana mengajarkan anak untuk menghargai waktu dengan bersikap disiplin.
\end{abstract}

Kata Kunci: Pendidikan Karakter, Permainan Tradisonal Gempuran, Anak Usia Dini

Abstract - This study aims to describe the character values contained in the traditional game of Gempuran performed by early childhood and to find out the positive and negative impacts of the traditional game of Gempuran. The method used is descriptive qualitative. Collecting data using interview, observation, and document techniques. The documents collected serve as supporting data. The validity of the data is seen when carrying out the traditional game of Gempuran, namely by checking and observing all activities carried out by educators and students in character building activities through the Gempuran game and conducting interviews with educators. The results show that there are character values in the traditional game Gempuran, namely a sense of mutual cooperation, democracy, unity, and obedience. These values become the basis for early childhood to carry out activities at the next age stage. Broadly speaking, there are positive impacts that can have a major impact on children's growth and development such as being able to socialize, children feel happy, children can be sporty, and make children creative. The negative impact is in terms of playing time, which can be overcome by limiting playing time. From the negative impact obtained, there are new findings obtained, namely how to teach children to respect time by being disciplined.

Keywords: Character Education, Traditional Games, Early Childhood 


\section{PENDAHULUAN}

$\mathrm{N}$ ilai-nilai di dalam Pancasila sudah dilakukan dalam budaya dan kebiasaan masyarakat Indonesia, jauh sebelum nilainilai tersebut dirumuskan dan ditetapkan secara resmi sebagai dasar negara Indonesia. Nilainilai yang menjadi tuntunan bagi bangsa Indonesia dalam berpikir, berucap dan bertindak.Ketika nilainilai ini menjadi landasan dalam berpikir dan berperilaku, maka jadilah nilai-nilai itu sebagai suatu falsafah bagi masyarakat Indonesia.Dengan landasan nilai-nilai luhur ini, maka masyarakat Indonesia menjadi tumbuh dan berkembang menjadi bangsa yang beretika moral.

Nilai-nilai Pancasila meresap dalam setiap cara berpikir masyarakat Indonesia dalam seluruh aspek kehidupan berbangsa. Termasuk dalam dunia pendidikan, khususnya dalam diri anak didik sebagai anak bangsa yang selalu berfalsafah Pancasila.Falsafah Pancasila akanmembawa anak didik untuk senantiasa membuka diri dalam setiap perubahan zaman, termasuk di masa globalisasi ini.Proses pembelajaran yang merdeka dapat melalui sekolah-sekolah yang mampu memberikan wadah bagi peserta didik untuk mengembangkan potensi dirinya, namun tetap sejalan dengan prinsipprinsip dari Pancasila. Hal ini secara tidak langsung telah memberikan proses pembudayaan karakter Pancasila secara merdeka kepada peserta didik (Zufar \& Thaariq, 2019).

Usia dini merupakan periode awal yang paling penting dan mendasar dalam rentang pertumbuhan serta perkembangan kehidupan manusia (Ramadhani, 2018). Pada masa ini banyak hal yang tidak bisa terlewatkan karena merupakan periode yang fundamental, yang menjadi dasar dalam pertumbuhan dan perkembangan pada masa-masa berikutnya.

Usia dini sering disebut sebagai usia emas atau golden age. Hal ini dapat dibuktikan karena pada rentang usia ini segala potensi yang ada dalam diri anak dapat lebih dikembangkan seperti potensi kecerdasan serta penanaman nilai-nilai positif dalam diri anak, yang akhirnya akan membentuk karakter dalam diri anak.

Menanamkan nila-nilai Pancasila pada anak usia dini bisa dilakukan dengan berbagai cara. Cara itu bisa dimulai dari hal-hal yang kecil yang mudah ditangkap, dipahami dan dilakukan oleh anak (Amu, 2021). Lebih lanjut, Amu (2021) menyatakan bahwa melalui pendidikan, nilai-nilai Pancasila dapat ditanamkan kepada anak didik dengan cara yang menyenangkan.

Nilai-nilai afektif dari dalam diri anak merupakan suatu usaha membangun manusia untuk mewujudkan sebuah karakter. Proses pembentukan manusia berkarakter dapat dilakukan oleh keluarga, satuan pendidikan, maupun lingkungan masyarakat. Pendidikan karakter merupakan usaha individual yang mau karena mampu untuk berkembang untuk menemukan makna lebih, nilai semangat (awareness) dan sikap (Ramadhani, 2018)

Salah satu cara yang harus dilakukan agar dapat mengatasi penurunan moral bangsa Indonesia pada setiap jenjang usia, khususnya pada anak usia dini adalah melalui pendidikan karakter. Hal ini dilakukan mengingat anak adalah generasi penerus bangsa maka kepribadian seorang anak haruslah memiliki moral yang kuat sehingga tidak mengalami degradasi moral. Menjadi tantangan tersendiri bagaimana mengajarkan nilai-nilai karakter pada anak usia dini sehingga anak mampu mengerti, memahami, serta menerapkannya pada kehidupan sehari-hari. Hingga pada akhirnya nilai karakter tersebut dapat melekat kuat dalam diri anak.

Pendidikan karakter merupakan pendidikan yang melibatkan penanaman pengetahuan, kecintaan, dan penanaman perilaku kebaikan yang menjadi sebuah pola kebiasaan pada pendidikan anak usia dini, yaitu nilai-nilai yang dipandang sangat penting dikenalkan dan diinternalisasikan ke dalam perilaku mereka. Nilai-nilai tersebut mencakup: kecintaan terhadap Tuhan Yang Maha Esa; kejujuran; disiplin; toleransi dan cinta damai; percaya diri; mandiri; tolong menolong, kerjasama, dan gotong royong; hormat dan sopan-santun; tanggungjawab; kerja keras; kepemimpinan dan keadilan; kreatif; rendah hati; peduli lingkungan; serta cinta bangsa dan Tanah Air (Maghfiroh, 2020). Di dalam menanamkan nilai-nilai pendidikan karakter anak usia dini bisa dilakukan dengan cara bermain. Slogan yang terdapat di pendidikan anak usia dini "Belajar sambil bermain, bermain seraya belajar", maka salah satu alat bermain yang bisa digunakan adalah permainan tradisonal (Andriani, 2012). Sebagai salah satu bentuk solusi untuk mengembalikan fungsi hakiki dalam memberikan layanan PAUD adalah melalui model permainan tradisional yang sejatinya menjadi bentuk kearifan lokal untuk membangun berbagai karakter pada anak usia dini (Hapidin \& Yenina, 2016). 
Akan tetapi, pengaruh modernisasi yang saat ini berkembang semakin pesat, menimbulkan sebuah tantangan besar dalam pembentukan karakter anak melalui permainan tradisional. Adanya pengaruh modernisasi dapat menimbulkan anggapan bahwa permainan tradisional kurang menarik. Sehingga, perlu dilakukan upaya agar permainan tradisional dapat menjadi aktivitas yang menarik untuk dilakukan dan menumbuhkan minat yang besar agar anak bersemangat dalam memainkan.

Permainan tradisional anak merupakan unsur-unsur kebudayaan yang tidak dapat dianggap remeh, karena permainan ini memberikan pengaruh yang tidak kecil terhadap perkembangan kejiwaan, sifat, dan kehidupan sosial anak dikemudian hari. Permainan tradisional yang teridentifikasi dapat menstimulus berbagai aspek perkembangan anak khususnya aspek keterampilan sosial (Zakiya, 2020). Memberikan kesempatan bagi anak-anak untuk bermain dengan teman-teman sebaya dapat meningkatkan keterampilan sosial dan emosional anak-anak (Ramadhani \& Fauziah, 2020). Selain itu, permainan ini juga dianggap sebagai salah satu unsur kebudayaan yang memberi ciri atau warna khas tertentu pada suatu kebudayaan. Oleh karena itu permainan tradisional anak-anak juga dapat dianggap sebagai aset budaya, sebagai modal bagi suatu masyarakat untuk mempertahanakan keberadaannya dan identitasnya di tengah kumpulan masyarakat yang lain.

Permainan tradisional merupakan warisan budaya bangsa yang sudah dimainkan sejak dulu (Adi, et al., 2020). Permainan tradisional mampu menstimulasi berbagai aspek perkembangan anak. Permainan tradisional dinilai dapat memberikan dampak yang baik untuk membantu pertumbuhan dan perkembangan anak dalam pembentukan karakter yang diinginkan. Di dalam sebuah permainan tradisional terdapat pengembangan ketrampilan emosi dan sosial anak. Banyak nilainilai yang terkandung dalam setiap rangkaian permainan yang memiliki makna yang penting bagi perkembangan anak usia dini baik dari segi motorik maupun psikologi anak usia dini.

Melalui permainan tradisional anak-anak dapat berekspresi. Dari sebuah ekspresi yang dikembangkan anak, akan melahirkan berbagai kreativitas maupun ketrampilan yang akan berguna bagi pertumbuhan dan perkembangan pada tahaptahap usia selanjutnya. Melalui permainan tradisonal, anak dapat belajar berbagai hal, diantaranya anak akan mengetahui bagaimana mengembangkan sebuah ide kreatif, bagaimana berusaha untuk mendapatkan sesuatu, serta bagaimana dapat memanfaatkan barang-barang yang ada di lingkungan sekitar.

Selain itu pengenalan permainan tradisonal pada anak usia dini merupakan salah satu tahapan awal tentang mengenalkan budaya bangsa Indonesia. Hal ini tentu saja dapat menumbuhkan motivasi dalam diri anak untuk tetap mencintai, menghargai, serta melestarikan budaya leluhur yaitu budaya Indonesia. Dengan melakukan permainan tradisional anak akan saling berkomunikasi yang secara tidak sadar dapat mengasah kemampuannya dalam berbahasa dan menambah kosa kata. Permainan tradisional dimainkan secara bersamasama, sehingga anak akan mengembangkan keterampilan sosialnya sendiri melalui pengalamannya (Maghfiroh, 2020).

Salah satu permainan tradisonal yang akan diusung untuk dapat lebih menumbuhkan nilai-nilai dalam berkarakter gotong royong, demokrasi, persatuan, dan kepatuhan adalah permainan tradisonal Gempuran.

Permainan tradisonal Gempuran dapat menjadi sebuah ide untuk anak tetap melaksanakan aktivitas dan tetap terpenuhi kebutuhan bermainnya. Karena kebutuhan dasar dari anak usia dini adalah bermain. Penelitian ini bertujuan untuk mendeskripsikan dan mengetahui nilai-nilai karakter yang terkandung dalam permainan tradisional Gempuran yang dilakukan oleh anak usia dini serta mengetahui dampak positif dan negatif dalam permainan tradisional Gempuran. Permainan tradisonal Gempuran mengandung makna yang dalam untuk dapat membantu pembentukan karakter pada anak usia dini. Nilai-nilai yang terkandung dalam permainan Gempuran ini antara lain rasa gotong royong, demokrasi, persatuan, dan kepatuhan. Nilai-nilai inilah yang sangat diperlukan untuk menjadi dasar anak usia dini kelak di dalam menjalani aktivitas pada tahap usia berikutnya.

Permainan tradisonal Gempuran berasal dari daerah Jawa Timur. Permainan ini membutuhkan beberapa perlengkapan sederhana dalam permainannya. Permainan Gempuran adalah suatu permainan anak-anak yang artinya menggempur atau menghancurkan. Menurut kamus bahasa Jawa, kata gempur adalah remuk ajur atau dalam bahasa Indonesia mempunyai makna usaha atau tindakan menghancur-leburkan. Nama ini, jika dikaitkan dengan permainan mempunyai motivasi untuk 
menghancurkan tumpukan pecahan gerabah yang, merupakan alat perlengkapan dari permainan.

Munculnya permainan ini dilatarbelakangi karena adanya kegiatan suatu desa dimana akan merobohkan tanggul untuk mengairi sawah. Karena pada masa itu terjadi kekeringan dimana air merupakan sumber yang penting bagi aktivitas pertanian. Para petani berusaha untuk mengalirkan air ke sawah-sawah mereka. Kegiatan ini dilakukan secara bersama-sama sehingga terjalin sikap gotong royong serta kerukunan yang baik antarwarga desa. Kerukunan dalam bergotong royong merupakan bagian dari kehidupan masyarakat di desa sehingga harus terus dipertahankan. Karena keinginan yang kuat untuk menumbuhkan sikap gotong royong, maka dibuatlah permainan Gempuran sebagai salah satu bentuk dari aksi nyata para petani. Hingga akhirnya permainan ini menjadi dikenal masyarakat luas.

Pada dasarnya permainan Gempuran ini adalah permainan yang sifatnya menghibur saja. Bisa dilakukan oleh siapa saja dan dimana saja karena permainan ini tidak menggunakan biaya. Permainan ini terdiri dari dua unsur yaitu bermain sekaligus berolah raga. Bukan hanya sehat badannya saja tetapi juga sehat jiwanya. Permainan ini dapat melatih ketangkasan dan ketrampilan anak-anak dalam gerak badan.

Alat-alat yang digunakan dalam permainan ini adalah bola terbuat dari sisa-sisa perca atau daun pisang kering yang digulung-gulung berbentuk bola kecil, dan dililit dengan berbagai macam tali yang dapat diperoleh di sekitarnya. Pecahan gerabah, kereweng atau tembikar, mudah diperoleh karena benda-benda itu merupakan sisa-sisa peralatan rumah tangga

Permainan ini dapat dimainkan oleh 2 kelompok, kelompok A dan kelompok B. Untuk jumlah anggota tidak dibatasi. Salah seorang sebagai wakil dari kelompoknya melakukan suit, untuk menentukan siapa yang menjadi penjaga dan siapa yang menjadi pelempar bola. Misalnya kelompok A yang menang suit menjadi pelempar dan kelompok B yang kalah menjadi penjaga.

Kelompok yang kalah, misal kelompok B, menyusun kepingan-kepingan pecahan genting atau gerabah. Kemudian menentukan jarak untuk memulai melempar bola yang dilakukan oleh kelompok yang menang, misal kelompok A. Untuk titik melempar dapat disepakati bersama. Misalnya dengan menentukan 5 langkah dari tumpukan pecahan genting. Dari titik yang sudah ditentukan inilah, para pelempar mulai dapat melempar bolanya yang diarahkan pada tumpukan pecahan genting atau gerabah.

Kelompok B berjaga di sekitar tumpukan gerabah, secara tersebar, merata, dengan perhitungan bahwa mereka siap menangkap bola sewaktu-waktu bola dilempar lawan. Kemudian pihak yang menang (kelompok A) bersiap-siap di sekitar titik lempar, lalu satu persatu melempar bola ke arah tumpukan gerabah dengan tujuan meruntuhkan dan menghancurkan.

Setiap pelempar hanya berhak melempar sampai tiga kali. Bila si pelempar sampai tiga kali melempar belum juga berhasil menghancurkan tumpukan pecahan gerabah, maka tugasnya segera digantikan teman berikutnya. Dan jika seluruh anggota kelompok tidak ada satu pun berhasil, maka kelompok itu berganti fungsi sebagai penjaga. Kelompok yang tadi berjaga (kelompok B) kini menjadi pelempar bola. Namun sebaliknya, apabila salah satu lemparan dari kelompok A mengenai sasaran, maka penjaga (kelompok B) harus secepatnya menangkap bola dan berusaha menembakkan bola ke arah tubuh lawan (kelompok A si pelempar bola), atau melemparkannya pada temannya yang lain dari kelompok B. Maksudnya agar teman tersebut (kelompok B) segera melemparkan bola untuk "ditembakkan" ke arah salah satu tubuh lawan (kelompok A si pelempar bola). Pembawa bola itu harus tetap berada di suatu tempat tertentu. Tetapi apabila tidak membawa bola, ia boleh mencari tempat yang strategis untuk siap menerima bola dan menembakkannya ke arah salah satu musuhnya yakni kelompok A.

Ada pun pihak pelempar bola (kelompok A) yang sekarang menjadi sasaran tembakan bola lawan (kelompok B), harus berusaha menghindar dari kemungkinan ditembak dengan bola. Mereka akan lari bercerai-berai menjauhi pemenang bola (anggota kelompok B). Namun, ketika bola ditembakkan dan tidak mengenai tubuh salah satu pemain lawannya (kelompok A), karena bola jauh terpelanting dan tidak tertangkap oleh Kelompok B, maka kelompok A harus berusaha menumpuk kembali pecahan gerabah yang porak-poranda tadi. Bila berhasil tanpa terkena tembakan bola, maka secepatnya anak yang bersangkutan meneriakkan kemenangannya dengan kata "horee..." Ini berarti Kelompok A memperoleh satu nilai. Dan permainan pun dimulai lagi seperti semula. 
Demikian seterusnya sampai salah satu kelompok mencapai nilai terbanyak berdasarkan kesepakatan bersama sebelum permainan dimulai. Jika ada kelompok yang memperoleh nilai banyak terlebih dahulu, maka kelompok itulah yang dinyatakan menang. Biasanya permainan ini berlangsung cukup lama, karena masing-masing kelompok harus mencapai "nilai banyak" dan untuk memperolehnya benar-benar memerlukan kerja sama kelompok yang sebaik-baiknya.

\section{METODE PENELITIAN}

Metode penelitian yang digunakan adalah metode kualitatif dengan pendekatan deskriptif, yang menggambarkan kejadian sebenarnya didukung dengan data berupa hasil observasi, wawancara, dan dokumentasi. Penelitian ini dilakukan di lingkungan TK PL Don Bosko Semarang pada tanggal 28 - 29 April 2021.

Adapun subyek penelitian ini adalah 2 orang pendidik dan 2 peserta didik. Teknik pengumpulan data diperoleh dengan observasi secara langsung dan melakukan wawancara dengan pendidik (Srikandi, 2020). Keabsahan data dilakukan pada saat memberikan kegiatan permainan tradisional Gempuran yaitu dengan mengecek dan mengobservasi segala aktivitas yang dilakukan oleh pendidik dan peserta didik dalam kegiatan pembentukan karakter.

\section{HASIL DAN PEMBAHASAN}

Kegiatan Permainan tradisional Gempuran dilaksanakan pada tanggal 28 - 29 April 2021 secara virtual di TK PL Don Bosko karena situasi pandemik Corona Virus Disease 2019 (Covid19) yang belum berakhir. Anak-anak bermain dengan anggota keluarga di rumah. Walaupun pandemik belum berakhir, tetapi penanaman nilai-nilai karakter tetap harus dilaksanakan.

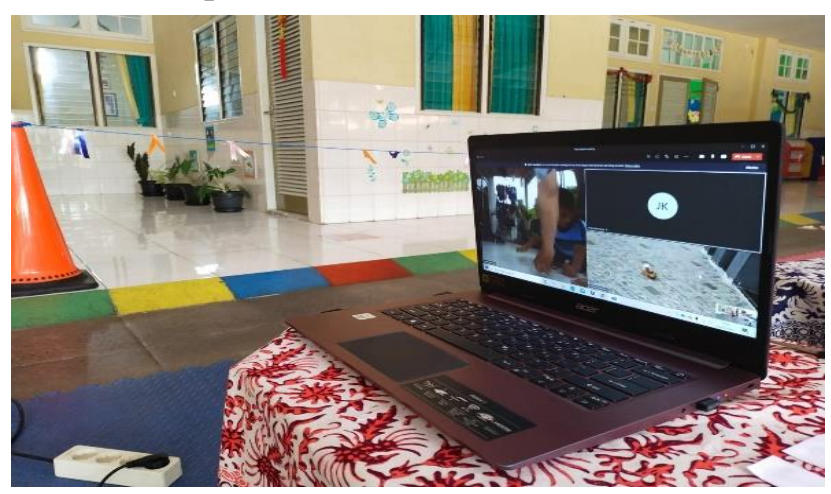

Gambar 1. Permainan Gempuran secara virtual
Sebelum kegiatan bermain dilakukan, pendidik mengajak anak-anak dan keluarga yang mendampingi untuk melakukan pemanasan. Anakanak mengikuti instruksi yang diberikan pendidik dengan tertib.Selanjutnya, pendidik menjelaskan kepada anak-anak tata cara permainan tradisional Gempuran, aturan-aturan yang harus dilaksanakan, serta alat-alat yang digunakan.Anak-anak melakukan permainan tradisonal Gempuran dengan baik dan menyenangkan.

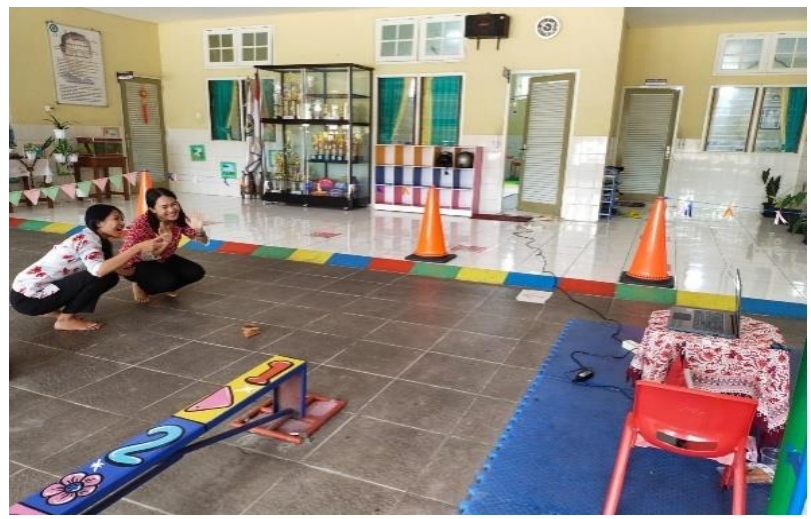

Gambar 2. Pendidik menjelaskan tentang cara permainan Gempuran

Saat melakukan permainan tradisonal Gempuran terlihat keseriusan, antusiasme, dan keaktifan anakanak dan pendidik dalam melakukannya. Menurut Adi, et al., (2020), permainan tradisional merupakan warisan budaya bangsa yang sarat akan nilai dan dapat digunakan untuk mengembangkan potensi anak, termasuk perkembangan sosial emosional anak. Perkembangan emosi maupun sikap pada saat melakukan permainan tradisional ini dapat diarahkan pada pembentukan karakter anak-anak. Melalui permainan ini sikap gotong royong, demokrasi, persatuan, maupun kepatuhan dapat ditanamkan pada anak. Selain itu, permainan juga dapat mendorong anak untuk berinteraksi, belajar bersosialisasi dengan lingkungan, serta mengendalikan perasaan.

Nilai-nilai karakter yang dapat dicapai melalui permainan tradisional Gempuran ini adalah:

a. Nilai Gotong Royong

Nilai gotong royong atau kemampuan bekerjasama sangat terlihat dalam permainan ini. Kerjasama di dalam satu kelompok sangat menentukan banyak nilai yang ingin dicapai. Misalnya, ketika salah seorang dari Kelompok A (pelempar bola) tidak berhasil melempar bola ke arah tumpukan gerabah, maka tugasnya digantikan oleh temannya yakni dari kelompok yang sama. Begitu pula bagi kelompok 
B, apabila lawannya (kelompok A) berhasil melempar dan mengenai sasaran tumpukan gerabah, maka bola harus segera ditangkap dan lalu melemparkannya kepada temannya yang sekelompok agar segera menembakkan ke arah salah satu tubuh lawan (kelompok A).Jadi maksudnya, agar kelompoknya (kelompok B) berganti fungsi jadi pelempar bola. Dengan demikian di sini tampak sekali kerja sama di antara para pemain.

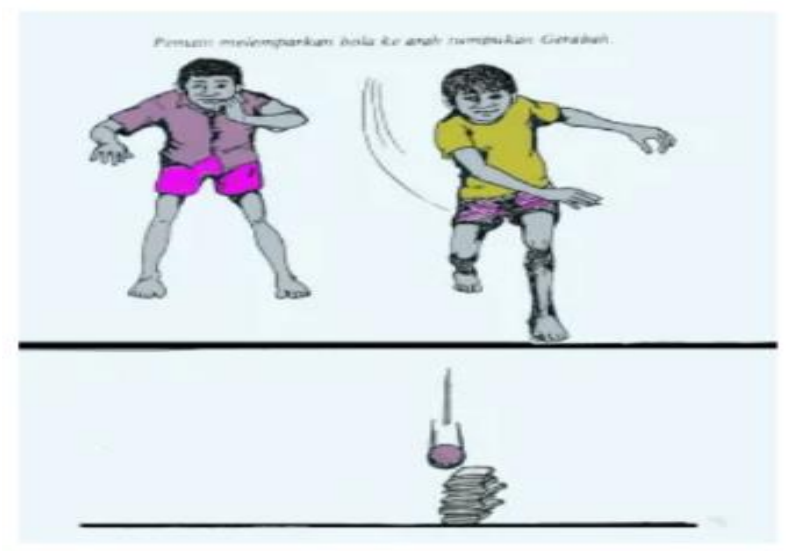

Gambar 3. Permainan Gempuran

(Sumber : jawatimuran.disperpusip.jatimprov.go.id)

\section{b. Nilai Demokrasi}

Yang dimaksud dengan demokrasi di sini adalah dalam pemilihan kawan dalam kelompok.Anak dapat diberikan kebebasan dalam memilih anggota kelompok. Anak diajarkan untuk belajar berdemokrasi dalam menentukan kelompoknya sendiri.

\section{c. Nilai Persatuan}

Rasa persatuan di dalam memainkan permainan ini tampak, yakni ketika kelompok A akan melawan kelompok B. Di sini masing-masing anggota kelompoknya bersatu sehingga menjadi suatu permainan yang benar-benar kompak.

\section{d. Nilai Kepatuhan}

Ketika salah satu kelompok telah berhasil memperoleh nilai dengan jumlah yang telah ditentukan sebelumnya, maka kelompok yang menang itu akan mendapatkan ucapan selamat dari teman-teman yang kalah ataupun belum menang.

Seluruh masyarakat Indonesia dalam segala aspek kehidupannya dan termasuk di dalamnya adalah dunia pendidikan yang harus selalu berjuang terus melakukan pembangunan kembali, melakukan inovasi, dan aktualisasi dari nilai-nilai luhur Pancasila di dalam kehidupan bermasyarakat, bangsa dan negara, di dalam penerapannya kepada anak didik. Oleh sebab itu filsafat Pancasila hendaklah dijadikan sebagai dasar dan landasan sumber daya untuk pendidikan nasional Indonesia, agar tercipta citra ideal bangsa. Supaya tujuan dari pendidikan karakter ini dapat berjalan serta berhasil dengan baik dan maksimal, maka sangat diperlukan dukungan luas dari semua pemangku kepentingan, pembuat kebijakan di masyarakat, golongan pendidik, orang tua, tokoh masyarakat, para pendidik, kepala sekolah, pemerintah pusat maupun pemerintah daerah.

Penanaman nilai-nilai Pancasila apabila ditanamkan sejak dini maka akan terbentuk karakter pribadi yang berbudi pekerti baik dan sesuai dengan nilai - nilai Pancasila. Hal ini dimaksudkan agar ketika anak tersebut dewasa sudah memiliki tingkah laku yang sesuai dengan nilai - nilai Pancasila (Kamila \& Dewi, 2021).

Pendidik sebagai salah satu ujung tombak pendidikan mempunyai peranan dalam pelestarian budaya. Peran pendidik dalam mengenalkan budaya dan nilai-nilai karakter di dalamnya menjadi penting (Adi et al., 2020). Pendidik pada lembaga PAUD menjadi aktor utama dalam pembentukan karakter anak di lingkungan sekolah (Witasari \& Wiyani, 2020).

Manfaat permainan tradisional Gempuran dapat dilihat dari beberapa aspek perkembangan anak yang mana dapat mendukung perkembangan dalam membentuk karakter anak usia dini. Manfaat tersebut, antara lain:

a. Aspek motorik

Dapat melatih daya tahan dan motorik kasar. Permainan ini didominasi dengan pergerakan fisik anak.

b. Aspek Kognitif

Dalam permainan ini mampu mengembangkan imajinasi, kreativitas, dan pemecahan masalah karena memerlukan kerjasama yang baik.

c. Aspek Emosi

Permainan ini mampu mengasah empati dan pengendalian diri pada masing-masing anak.

d. Aspek Bahasa

Permainan ini dapat mengembangkan konsepkonsep dalam berkomunikasi yang baik. Bentuk permainan yang berupa tim, diharapkan terjalin komunikasi antar pemain yang satu dengan pemain yang lain.

Kegiatan permainan merupakan kegiatan yang sangat disukai oleh anak-anak. Dunia anak yang 
selalu melekat dalam ingatan adalah dalam bentuk permainan. Melalui permainan, kegembiraan dan sukacita dapat mengalir dengan mudah.Aktivitas bermain bagi anak melibatkan segala aspek perkembangan, seperti aspek kognitif, afektif, fisik motorik, bahasa dan sosial emosional (Husain \& Walangadi, 2020)

Adapun dampak dari permainan tradisional Gempuran ini adalah:

a. Dampak Positif, yaitu: 1). Anak dapat bersosialisasi dengan teman ataupun saudara yang bermain bersama sehingga tercipta sikap saling menyanyangi dan toleransi; 2). Mengajarkan anak untuk bersikap sportif. Dengan sikap sportif ini akan mengajak anak untuk mengelola rasa egosentris dalam diri anak; 3). Anak akan merasa sehat dan senang. Karena permainan tradisonal Gempuran ini terdapat unsur olahraga; dan 4). Menjadi anak yang kritis dan kreatif. Dengan permainan tradisonal anak akan belajar memikirkan strategi-strategi yang akan dilakukan agar dapat memenangkan dalam permainan tradisonal.

b. Dampak Negatif, yaitu: tidak disiplin dalam waktu. Permainan tradisonal merupakan permainan yang sangat menyenangkan. Jika tidak diatur waktunya, maka anak akan keasyikan sehingga anak tidak ingat waktu. Hal ini pun dapat menjadi perhatian untuk dapat menumbuhkan sikap disiplin pada anak. Dengan adanya pembatasan waktu yang telah ditentukan, diharapkan dapat menumbuhkan sikap disiplin pada anak.

Dari dampak negatif yang diperoleh maka terdapat temuan baru yang didapatkan, yaitu bagaimana mengajarkan anak untuk menghargai waktu dengan bersikap disiplin. Disiplin juga merupakan nilai karakter yang harus ditanamkan pada anak usia dini.

Pendidikan karakter merupakan pendidikan yang melibatkan penanaman pengetahuan, kecintaan, dan penanaman perilaku kebaikan yang menjadi sebuah pola kebiasaan pada pendidikan anak usia dini, yaitu nilai-nilai yang dipandang sangat penting dikenalkan dan diinternalisasikan ke dalam perilaku mereka. Nilai-nilai tersebut mencakup: kecintaan terhadap Tuhan Yang Maha Esa; kejujuran; disiplin; toleransi dan cinta damai; percaya diri; mandiri; tolong menolong, kerjasama, dan gotong royong; hormat dan sopan-santun; tanggungjawab; kerja keras; kepemimpinan dan keadilan; kreatif; rendah hati; peduli lingkungan; serta cinta bangsa dan Tanah Air (Maghfiroh, 2020). Dengan demikian maka diharapkan program pendidikan karakter berbasis sekolah dapat berjalan dengan baik, efisien, efektif, serta tepat sasaran. Untuk itu sangat diperlukan dukungan luas dari pihak sekolah, yakni keluarga dan sekolah untuk semakin giat menanamkan nilai-nilai pendidikan karakter dalam diri anak didik. Hal ini tidak mungkin hanya dilakukan dengan melalui nasihat atau pelajaran secara teori yang diberikan kepada anak didik, tetapi terutama melalui keteladanan hidup dan bersikap.

\section{SIMPULAN DAN SARAN}

Penanaman nilai-nilai Pancasila apabila ditanamkan pada anak sejak dini maka akan terbentuk karakter yang baik atau memiliki pribadi yang berbudi pekerti sesuai dengan nilai-nilai Pancasila. Menanamkan nilai-nilai karakter pada anak dapat dilakukan dengan cara bermain, salah satunya adalah permainan tradisional Gempuran. Dalam permainan tradisonal Gempuran pendidikan karakter yang tertanam adalah gotong royong, demokrasi, persatuan, dan sikap sportivitas dalam diri anak.

Dampak positif dari permainan ini adalah anak dapat bersosialisasi, anak merasa senang, anak dapat bersikap sportif, serta menjadikan anak kreatif. Adapun dampak negatif yaitu dalam hal penggunaan waktu bermain.

Adapun saran yang dapat diberikan adalah bahwa untuk mengajarkan sikap disiplin pada anak, sebaiknya diawali dengan membuat kesepakatankesepakatan ataupun aturan mulai dari awal permainan tradisional ini. Kesepakatan tentang pembatasan waktu sangat diperlukan. Hal ini dilakukan agar tercipta kedisiplinan dalam diri anak usia dini.

\section{DAFTAR PUSTAKA}

Adi, B. S., Sudaryanti, S., \& Muthmainah, M. (2020). Implementasi permainan tradisional dalam pembelajaran anak usia dini sebagai pembentuk karakter bangsa. Jurnal Pendidikan Anak, 9(1), 33-39.

https://doi.org/10.21831/jpa.v9i1.31375

Amu, S. (2021). Metode Penanaman Nilai-Nilai Pancasila Pada Anak Usia Dini di Taman Kanak-Kanak Kecamatan Pinolosian Kabupaten 
Bolaang Mongondow Selatan. KIDSPEDIA : Jurnal Pendidikan Anak Usia Dini, 2(1), 1-10.

Andriani, T. (2012). Permainan Tradisional Dalam Membentuk Karakter Anak Usia Dini. Jurnal Sosial Budaya, 9(1), 121-136.

Hapidin, \& Yenina. (2016). Pengembangan Model Permainan Tradisional. Jurnal Pendidikan Usia Dini, 10(2), 201-212.

Husain, R. I., \& Walangadi, H. (2020). Permainan Tradisional Gorontalo dalam Menumbuhkan Nilai-Nilai Karakter Anak. Jurnal Obsesi : Jurnal Pendidikan Anak Usia Dini, 5(2), 13521358. https://doi.org/10.31004/obsesi.v5i2.839

Kamila, jenisa T., \& Dewi, D. A. (2021). Pentingnya Mengenalkan Pancasila Dan Contoh Penerapan Nilai - Nilai Pancasila Sejak Anak Berusia Dini. Indonesian Journal of Mustidisiplinary Islamic Studies, 2(2), 81-92.

Maghfiroh, Y. (2020). Peran Permainan Tradisional dalam Membentuk Karakter Anak Usia 4-6 Tahun. Jurnal Pendidikan Anak, 6(1), 1-8.

Ramadhani, A. (2018). Seminar Nasional IPTEK Olahraga. Identifikasi Nilai-Nilai Pendidikan Karakter Dalam Permainan Anak Tradisional, 6-10.

https://ejournal.unibabwi.ac.id/index.php/semna ssenalog/article/view/175
Ramadhani, P. R., \& Fauziah, P. Y. (2020). Hubungan Sebaya dan Permainan Tradisional pada Keterampilan Sosial dan Emosional Anak Usia Dini. Jurnal Obsesi : Jurnal Pendidikan Anak Usia Dini, 4(2), 1011. https://doi.org/10.31004/obsesi.v4i2.502

Witasari, O., \& Wiyani, N. A. (2020). Permainan Tradisional untuk Membentuk Karakter Anak Usia Dini. JECED : Journal of Early Childhood Education and Development, 2(1), 52-63. https://doi.org/10.15642/jeced.v2i1.567

Zakiya, F. mayar. (2020). Menstimulasi keterampilan sosial anak usia dini melalui seni permainan tradisional. Ensiklopedia of Journal, 53(9), 1689-1699.

Zufar, Z., \& Thaariq, A. (2019). Pembudayaan Pendidikan Karakter Pancasila.

https://jawatimuran.disperpusip.jatimprov.go.id/20 12/09/18/gempuran/ 